\title{
Construindo a accountability em portais eletrônicos de câmaras municipais: um estudo de caso em Santa Catarina
}

\author{
Building accountability in websites of local councils: a case study in \\ Santa Catarina (Brazil)
}

Fabiano Maury Raupp

José Antonio Gomes de Pinho²

\begin{abstract}
Resumo
O portal eletrônico é considerado uma tecnologia capaz de possibilitar condições para a construção da accountability dos atos públicos. Contudo, a confirmação da utilização do portal eletrônico com esse propósito carece de pesquisas empíricas, particularmente, em relação às câmaras municipais, haja vista que a literatura apresenta pesquisas com o Poder Executivo. Objetivou-se, portanto, investigar as condições de construção da accountability em portais eletrônicos de câmaras municipais. Para tanto, foram observados 17 portais de câmaras municipais do estado de Santa Catarina, cujos municípios possuem mais de 50.000 habitantes. A construção do modelo de análise levou em consideração indicadores de baixa, média e alta capacidade para a prestação de contas, a transparência e a busca da participação/interação com o cidadão, sendo essas as dimensões da accountability observadas. A maioria das constatações remete a uma média capacidade dos portais eletrônicos de promoverem condições para o processo de prestação de contas. Já em relação à transparência dos atos públicos, há uma propensão de alta capacidade dos portais de promovê-la. No tocante à participação/interação dos cidadãos com o ente analisado, o que se percebe é uma baixa capacidade dos portais.
\end{abstract}

Palavras-chave: accountability; portais eletrônicos; câmaras municipais; Santa Catarina.

\begin{abstract}
Website is considered a technology capable of providing conditions for building accountability in the public sphere. However, the use of websites for this purpose needs empirical research, particularly regarding the Local Councils, considering that research has been developed on the executive branch of public sphere. The objective of this article is to investigate the conditions of accountability in the Local Councils' websites. To do this, 17 websites of Local Councils of towns with more than 50,000 inhabitants in the state of Santa Catarina, in the Brazilian's South region, were observed. The model of analysis took into account three dimensions: accountability, transparency and the willingness of citizen participation/interaction according to three levels: low, medium and high capacity. The majority of findings reveals a medium capacity of websites to promote conditions for building accountability. The findings stress a high capacity of transparency, which can be considered the most valuable result. On the other hand, as far as interaction/participation is concerned, a low capacity was identified in the websites as a whole.
\end{abstract}

Key words: accountability; websites; local councils; Santa Catarina.

Artigo submetido em fevereiro de 2010 e aceito para publicação em agosto de 2010

\footnotetext{
1 Doutorando pela Escola de Administração da Universidade Federal da Bahia (EA/UFBA), mestre em administração pela Curso de Pós-Graduação em Administração da Universidade Federal de Santa Catarina (CPGA/UFSC), professor da Escola Superior de Administração e Gerência da Universidade do Estado de Santa Catarina (ESAG/UDESC). Endereço: Universidade do Estado de Santa Catarina, Escola Superior de Administração e Gerência. Av. Madre Benvenuta, 2.037, Itacorubi, Florianópolis, SC, Brasil, CEP 88035-001. E-mail: fabianoraupp@hotmail.com.

${ }^{2}$ Doutor em planejamento regional pela University of London (LSE), professor associado I da UFBA, coordenador do Núcleo de Pós-Graduação da Escola de Administração da UFBA. Endereço: Universidade Federal da Bahia, Escola de Administração. Av. Reitor Miguel Calmon, s/n, Vale do Canela, Salvador, BA, Brasil CEP 40110-100,. E-mail: jagp@ufba.br.
} 


\section{Introdução}

A expressiva disseminação das tecnologias da informação e comunicação (TICs), através de diferenciados instrumentos, tem promovido avanços em diversos setores, como é o caso do setor público, que tem implementado instrumentos com o objetivo de tornar a gestão governamental mais eficiente. O governo eletrônico é uma dessas iniciativas e tem disponibilizado serviços à sociedade, além de possibilitar uma aproximação entre o cidadão e o ente governamental, contribuindo, em tese, para uma maior democratização dos processos, expressa pela accountability. Um dos mecanismos utilizados para operacionalizar o governo eletrônico é a implementação de portais eletrônicos.

As TICs também têm se espraiado por outros setores do Estado, tais como os poderes Legislativo e Executivo, visando aos mesmos objetivos: maior eficiência e maior transparência, o que pressupõe maior abertura ao diálogo com a sociedade. Neste artigo, optou-se por analisar os portais eletrônicos no âmbito do Poder Legislativo local, por duas razões principais. A primeira é a escassez de estudos sobre essa esfera de governo. A segunda, interligada à primeira, relaciona-se ao crescente interesse por esse poder devido ao seu papel crucial numa democracia e numa federação como o Brasil. Para Santos (1998, p.713), "cada vez mais o Poder Legislativo, sua estrutura e decisões conquistam o interesse de analistas profissionais e curiosos amadores da política brasileira".

Neste estudo, parte-se do entendimento de que, dependendo dos objetivos e da forma como são implementados, os portais eletrônicos podem contribuir para a construção da accountability. Evidentemente, corre-se o risco, quando da criação de um portal eletrônico, de que não haja transparência, prestação de contas e nem participação/interação com os cidadãos, dimensões da accountability analisadas no estudo, e que o mesmo possa servir apenas de mural eletrônico. No entanto, são necessárias pesquisas empíricas que apresentem evidências, para que se possa afirmar ou refutar os portais eletrônicos como tecnologia de promoção da accountability.

A investigação sobre a construção da accountability em portais eletrônicos de câmaras municipais ainda é incipiente. Normalmente, os estudos abordam o Executivo, como ocorre com os trabalhos de Akutsu (2005), Akutsu e Pinho (2002), Amaral (2007), Menezes (2006), Pinho (2006, 2008), Prado (2004) e Vaz (2003).

O objetivo deste artigo é investigar as condições de construção da accountability em portais eletrônicos de câmaras municipais. Para tanto, foram analisados 17 portais eletrônicos de câmaras municipais do estado de Santa Catarina, com o intuito de se observar como são construídas as condições para a prestação de contas e para que haja transparências nos atos públicos e participação/interação com os cidadãos. Inicialmente, fez-se uma breve incursão teórica sobre patrimonialismo, democracia delegativa, accountability, Legislativo eletrônico e Legislativo municipal, corpos teóricos entendidos como necessários para o enquadramento do objeto empírico em observação. Em seguida, descreve-se o método de pesquisa. Na sequência, procede-se à descrição e à análise dos dados coletados. Por fim, são apresentadas as considerações finais.

\section{Patrimonialismo, democracia delegativa e accountability}

Schwartzman defende que a realidade brasileira pode ser melhor explicada por um referencial weberiano do que marxista, pois no Brasil vigoram componentes não baseados em relações de classe que são extremamente importantes para o entendimento do poder, tais como, estruturas de poder local e regional baseadas em lideranças tradicionais, ainda poderosas, que não seguem os ditames das estruturas de classe e das sociedades modernas, industriais (SCHWARTZMAN, 1988). Desse modo, neste artigo, vamos seguir um referencial weberiano, começando justamente por seu criador, a respeito do tipo de dominação patrimonialista. 
Na definição de Weber (1944), o patrimonialismo constitui uma forma de dominação tradicional, caracterizada pela organização do poder político de forma análoga ao poder doméstico do governante. Despojado de sua dimensão pública, o poder, nos moldes do patrimonialismo, constitui um direito próprio (do soberano), apropriado como qualquer outro objeto de sua propriedade.

Partindo da concepção de Weber, "patrimonialismo significa a incapacidade ou a relutância do príncipe em distinguir entre o patrimônio público e seus bens privados" (BRESSER PEREIRA, 1997, p.10). No patrimonialismo, o governante trata a administração política como seu assunto pessoal, igualmente como explora a posse do poder político como um predicado útil de sua propriedade privada, onde as esferas pública e privada se confundem nas práticas dos governantes. A administração patrimonial consiste em administrar e proferir sentenças caso por caso, combinando o exercício discricionário da autoridade pessoal com a consideração devida pela tradição sagrada ou por certos direitos individuais estabelecidos (BENDIX, 1986).

A administração pública brasileira, em particular, e o Estado brasileiro, em geral, foram fundados sob a influência de um etos fortemente patrimonialista, presente na herança cultural lusitana (MARTINS, 1997). No período colonial brasileiro, o Estado adotou um modelo patrimonialista e centralizador. Sempre foi poderoso, autoritário, autolegitimado, estabelecendo com a sociedade uma relação de tutela e subordinação. Não definiu limites claros entre o público e o privado, estabelecendo, como moedas de troca política, terras e cargos públicos. A administração decorrente desse processo orientou-se mais para a prestação de serviços aos governantes do que para a sociedade (AMORIM, 2000).

O Estado brasileiro, sobretudo, no período colonial, sempre garantiu às suas elites privilégios e benesses adquiridos em função das relações e correlações de forças políticas existentes nas ações e intervenções do Estado na sociedade. O principal marco de afirmação e consolidação do patrimonialismo foi a transferência para o Brasil de parte da burocracia lusitana juntamente com a corte portuguesa. Isso fez com que vícios e práticas clientelistas, nepotistas, e centralizadoras, determinassem o perfil político-administrativo brasileiro: um modelo de administração pública patrimonial (SOUZA, 2007).

Segundo Buarque de Holanda (1969), durante e após a colonização, não era fácil aos detentores das posições públicas de responsabilidade, formados por tal ambiente, compreenderem a distinção fundamental entre os domínios do privado e do público. A escolha dos homens que irão exercer as funções públicas faz-se muito mais pela confiança pessoal que mereçam os candidatos do que por sua própria capacidade. A tudo falta a ordenação impessoal que caracteriza a vida no Estado burocrático.

Faoro (1998) afirma que em algumas regiões, notadamente no Nordeste, o patrimonialismo, cujas marcas estão impregnadas no dia a dia da sociedade, fomentou o surgimento de problemas e disfunções na administração de organizações públicas de diversos setores. Há uma frequente utilização dos poderes políticos e das instituições para se continuar a exercer, com legitimidade, a dominação e o regime de enriquecimento de uma camada da sociedade.

Segundo Schwartzman (1988), os regimes patrimoniais modernos são denominados neopatrimonialistas. O neopatrimonialismo não é simplesmente uma sobrevivência das estruturas tradicionais em sociedades contemporâneas, mas uma forma bastante atual de dominação política por um estrato social sem propriedades e que não tem honra social por mérito próprio, ou seja, pela burocracia e a chamada classe política.

Além da manutenção de características patrimonialistas, é importante considerar que a democracia representativa não é capaz de explicar a totalidade do processo democrático brasileiro. O contexto latinoamericano possui características de um modelo de democracia proposto por Guillermo O'Donnell, denominado democracia delegativa. Mesmo seguindo os parâmetros da democracia representativa, esta seria insuficiente para explicar e entender a realidade latino-americana ao ser contaminada pela referência da democracia delegativa.

A democracia delegativa se fundamenta em uma premissa básica: aquele que ganha uma eleição presidencial é autorizado a governar o país como lhe parecer conveniente, na medida em que as relações de poder existentes 
permitam, até o final de seu mandato. Os candidatos presidenciais vitoriosos nas democracias delegativas se apresentam como estando acima de todas as partes; isto é, dos partidos políticos e dos interesses organizados (O’DONNELL, 1991).

Na democracia delegativa, o povo outorga plenos poderes a seu governante, que reforça seu papel de tutor. Os eleitores conferem ao governante plenos poderes, enquanto nas democracias representativas os governantes estão amarrados às promessas de campanha, devendo prestar contas de seus atos. A distinção entre esses dois tipos de democracia encontra-se na accountability: fraca (ou inexistente), nas democracias delegativas, e consolidada nas democracias representativas estáveis (PINHO, 2008). Mesmo que a democracia delegativa pertença ao gênero democrático, seria difícil encontrar algo que seja mais estranho, quando não hostil, à construção e ao fortalecimento de instituições políticas democráticas. A democracia delegativa representa para o presidente a vantagem de não ter praticamente nenhuma obrigatoriedade de prestar contas (O'DONNELL, 1991).

Instituições como o Congresso e o Judiciário são incômodos que acompanham as vantagens de ser um governante democraticamente eleito. A ideia de obrigatoriedade de prestar contas a essas instituições aparece como um impeditivo desnecessário ao pleno exercício da autoridade que lhe foi delegada pelo voto (O’DONNELL, 1991).

Ceneviva e Farah (2006) aduzem que O'Donnell foi certamente um dos pioneiros a relacionar as vicissitudes de uma modalidade delegativa de democracia na América Latina ao que denominou déficit de accountability dos sistemas políticos que se erigiam na região. Seu juízo tinha como base a observação de que o restabelecimento da competição eleitoral não foi suficiente para assegurar um controle satisfatório da atuação de governantes e demais decisores políticos.

Ao se referir ao contexto brasileiro, Akutsu e Pinho (2002) arriscam-se a afirmar que em regiões menos patrimonialistas ocorrem maiores avanços democráticos, e em regiões mais patrimonialistas essa velocidade é menor ou existe mesmo paralisia. A história mostra que essas estruturas não são rompidas com facilidade e num movimento linear. A transformação muito provavelmente se dará a partir de dois movimentos: um que vai do Estado em direção à sociedade e outro, desta em direção ao Estado.

Para Miguel (2005), a accountability ganha destaque nos estudos sobre patrimonialismo e democracia delegativa por prometer um grau razoavelmente alto de controle do povo sobre os detentores do poder político, mas de uma forma exequível em sociedades populosas, extensas, complexas e especializadas como as contemporâneas.

Segundo Campos (1990), o conceito de accountability não possui uma expressão equivalente em português que contemple o espectro de significados existentes no termo em inglês. É praticamente um lugar-comum observar que accountability não possui tradução precisa para o português (e para outras línguas neolatinas) e, daí, extrair conjecturas sobre a qualidade de nossas democracias em comparação com as anglo-saxãs (MIGUEL, 2005).

Vinte anos se passaram desde que Anna Maria Campos expôs a ausência do conceito e, consequentemente, de uma palavra que no dicionário da língua portuguesa traduzisse com perfeição o significado de accountability. Observa-se, desde então, que o cenário político brasileiro mudou substancialmente: uma nova Constituição Federal foi elaborada, a democracia se consolidou e reformas no aparelho do Estado foram empreendidas com a promessa de tornar a administração pública mais eficiente e, inclusive, mais controlável. Paralelamente, uma imensa literatura tem sido produzida no intuito de analisar e compreender os impactos de tais mudanças no tecido social, bem como suas contribuições para viabilizar, pelo menos, uma aproximação do conteúdo do conceito de accountability com a realidade da administração pública brasileira (PINHO; SACRAMENTO, 2009).

Accountability, em termos sintéticos e aproximativos, pode ser pensada como a transparência, o engajamento dos governantes na prestação de contas e, também, a responsabilização dos governantes pelos seus atos 
(PINHO; SACRAMENTO, 2009). O conceito de accountability, conforme Akutsu e Pinho (2002, p.731), contempla duas partes:

a primeira delega responsabilidade para que a segunda proceda à gestão dos recursos; ao mesmo tempo, gera a obrigação daquele que administra os recursos de prestar contas de sua gestão, demonstrando o bom uso desses recursos.

A accountability não emerge por si só, mas é determinada por uma relação entre o Estado e a sociedade, propiciada pelo desenvolvimento democrático. É resultado de um desenvolvimento político que confere ao cidadão um papel ativo de sujeito, guardião de seus direitos (CAMPOS, 1990). A accountability não é um predicado dos sujeitos; ao contrário, é um atributo do sistema político que se impõe aos agentes públicos, sejam estes governantes ou burocratas (CENEVIVA; FARAH, 2006).

Loureiro e Abrucio (2004, p.52) entendem por "accountability ou responsabilização um processo institucionalizado de controle político estendido no tempo (eleição e mandato) e no qual devem participar, de um modo ou de outro, os cidadãos organizados politicamente". Destacam ainda a necessidade de regras e arenas nas quais a accountability possa ser exercida, bem como práticas de negociação ampliadas entre os atores, a fim de tornar mais públicas e legítimas as decisões tomadas.

O estudo da accountability envolve a análise de diferentes mecanismos institucionais de responsabilização. Para O'Donnell, esses mecanismos são divididos em duas vertentes principais. A primeira é a accountability vertical, que tem nas eleições o instrumento principal, possibilitando a efetivação de mecanismos tradicionais como a premiação e o castigo. A segunda é a accountability horizontal, contemplando o tema da divisão dos poderes e dos controles e equilíbrios entre eles (O'DONNELL, 1998). Na primeira, os cidadãos eleitores podem controlar as ações desempenhadas pelo representante durante seu mandato. Na segunda, os poderes possuem mecanismos capazes de questionar e, eventualmente, punir maneiras impróprias do ocupante do cargo em questão cumprir suas responsabilidades (O’DONNELL, 1991). Nesse conjunto de formulações tem-se uma aproximação explícita com o tema desta investigação: ao controlar as ações desempenhadas pelos representantes eleitos, não se está apenas tratando de cargos executivos, mas, também, de cargos do Legislativo. Nesse sentido, a accountability assume uma importância muito mais ampla e abrangente ao compreender todos os cargos eletivos.

As eleições, as reivindicações sociais e a cobertura regular da mídia são consideradas dimensões da accountability vertical. As eleições devem apresentar características de liberdade de expressão, de cobertura de imprensa e liberdade de associação que permita aos cidadãos vocalizarem suas demandas, denunciar os oficiais públicos e sancioná-los. O que pode ser definido como o instrumento principal da accountability vertical, as eleições, ocorre apenas de tempos em tempos. Porém, não está claro até que ponto elas são efetivas como mecanismos de accountability. Análises recentes lançam uma nota cética quanto ao grau em que a eleição seja verdadeiramente um instrumento pelo qual os eleitores podem punir ou premiar candidatos, mesmo em poliarquias fortemente institucionalizadas (O’DONNELL, 1998).

A accountability horizontal, conforme O'Donnell (1998), pode ser entendida como a existência de agências estatais que têm o direito e o poder legal - e que estão de fato dispostas e capacitadas - para realizar ações, que vão desde a supervisão de rotina até sanções legais ou, mesmo, o impeachment contra ações ou emissões de outros agentes ou agências do Estado que possam ser qualificados como delituosos. Nessa dimensão, os poderes devem apresentar um grau de concorrência e equilíbrio, como o sistema de divisão de poderes do presidencialismo, além de órgãos independentes com poder, incentivos e capacidade de ação em relação a outros órgãos governamentais.

Tanto do ponto de vista vertical quanto horizontal, o exercício da accountability requer condições para que haja a disponibilidade de informações sobre a atuação do poder público e seus resultados, ou seja, prestação de contas. Contudo, torna-se relevante a existência de instituições que possam contestar as informações veiculadas (PÓ; ABRUCIO, 2006). A prestação de constas como dimensão da accountability, segundo Levy 
(1999), refere-se não somente à premissa da prestação de contas, mas também à definição dos objetos sobre os quais se prestarão contas.

Outra dimensão da accountability capaz de proporcionar maiores condições de confiança entre governantes e governados é a transparência das ações governamentais. A transparência é citada como capaz de contribuir para reduzir a corrupção no espaço público e de tornar as relações entre o Estado e a sociedade civil mais democráticas (PINHO; SACRAMENTO, 2004). A transparência governamental é uma condição sine qua non para o funcionamento dos mecanismos de responsabilização, já que, de fato, esses mecanismos de controle e fiscalização são extremamente condicionados pela transparência e pela visibilidade das ações do poder público. Sem transparência, fidedignidade e clareza das informações não há como cidadãos apropriarem-se dos dados das avaliações para cobrarem dos agentes públicos (CENEVIVA; FARAH, 2006).

A participação/interação dos cidadãos no processo decisório do ente governamental é uma dimensão da accountability tão importante quanto a prestação de contas e a transparência. Santos (1993) observa no Brasil uma enorme massa urbanizada, incapaz de participação ou desmotivada para isso, além de uma baixa taxa de demandas, do descrédito tanto nas instituições quanto na eficácia do Estado, bem como uma permanente negação de conflito. Nessa mesma linha, Pinho (2008) considera que o Brasil estaria numa situação de fraca accountability, em que não há participação por parte da sociedade, no sentido de exigir maior transparência do Estado, o qual se comporta de acordo com um modelo histórico de insulamento em relação à sociedade civil. Por sua vez, Abrucio (2005) afirma que é notável o grau de participação dos cidadãos nas políticas sociais. Torna-se necessário ativar esse processo onde ele tem maior incidência, isto é, no plano descentralizado de poder. A questão da participação parece tornar-se central no sentido do aperfeiçoamento da democracia e da accountability. No entanto, não há consenso entre os autores sobre essa questão. Assim, enquanto Santos e Pinho afirmam que não há participação, Abrucio traça um quadro em que a participação tem aumentado.

\section{Do governo eletrônico ao Legislativo eletrônico}

As tecnologias da informação e comunicação (TICs) - entre as quais se destacam a Internet, as redes de computadores, a transmissão via satélite e a telefonia móvel - criaram condições para o surgimento da sociedade do conhecimento. O Estado, por intermédio do governo eletrônico (e-gov), é o principal instrumento de que os cidadãos dispõem atualmente para enfrentar os desafios impostos pela globalização, por meio de interações inéditas entre sociedade, empresas e governos (BRAGA et al, 2008).

A diminuição das barreiras de acesso à informação reconfigura a estrutura tradicional da prática política. Consultar oportunidades de emprego, contatar representantes políticos, acompanhar a utilização das verbas públicas ou propor agenda de discussão das políticas públicas torna-se possível a partir das tecnologias de informação e comunicação, canais de que os governos se apropriam para disponibilizar vários serviços aos cidadãos (SANTOS, 2009).

Ruediger (2002) afirma que o governo eletrônico, apesar de marcado pelo desenvolvimento de sistemas relativos ao provimento de serviços, contempla também uma possibilidade de extensão da esfera do Estado propícia a uma maior permeabilidade à cidadania, decorrente do caráter intrinsecamente político da ação governamental.

O governo eletrônico, segundo Pinho (2008) não pode ser visto apenas do ângulo técnico, entendido apenas como uma possibilidade tecnológica. O governo eletrônico não deve ser visto apenas como resultado do surgimento dos dispositivos da TIC. Também deve ser considerada a abertura de uma vasta gama de possibilidades de interação e de participação entre governo e sociedade, além do compromisso de transparência por parte do governo, ou seja, atividades de cunho essencialmente político. 
Em termos gerais, pode-se pensar nas seguintes relações sustentadas pelo governo eletrônico: 1) aplicações Web com foco no segmento governo-fornecedor (G2B - government to business); 2) aplicações Web voltadas para a relação governo-cidadão (G2C - government to costumer); e 3) aplicações Web referentes a estratégias governo-governo ( $\mathrm{G} 2 \mathrm{G}$ - government to government). O governo eletrônico, além de promover essas relações em tempo real e de forma eficiente, poderia ainda ser potencializador de boas práticas de governança, além de catalisador de uma mudança profunda nas estruturas de governo, proporcionando mais eficiência, transparência e desenvolvimento (RUEDIGER, 2002).

Para Vaz (2003), os benefícios do governo eletrônico são apontados como apropriáveis pelo governo (aumento da capacidade operativa, ganhos de eficiência, melhor relacionamento com os cidadãos). Também podem ser vistos a partir de outro ponto de vista, o do cidadão (melhor atendimento, acesso a serviços e a informações e condições de interagir com governo).

Segundo Cardoso (2004), com o governo eletrônico ocorre uma profunda alteração nas formas pelas quais os cidadãos interagem com seus representantes e governantes, em termos de transmitir seus desejos, aspirações e necessidades, opinar sobre iniciativas, projetos ou políticas governamentais ou, ainda, acompanhar e controlar a ação daqueles que os representam e governam.

A efetivação dos serviços propiciados pelo governo eletrônico pode ser facilitada pela utilização de portais eletrônicos. Um portal é uma porta de entrada na rede mundial. Pode assumir a configuração de sites públicos que permitem ao cidadão realizar um conjunto de serviços. A partir do portal, muitos usuários definem seus próximos passos na Web. Os portais representam locais de intensa visitação. Portanto, ser reconhecido como um portal está diretamente relacionado à força com que o site atrai visitantes. Os serviços mais comuns de um portal incluem o de e-mail, bate-papo (chat) e de busca, além dos serviços de notícias, gratuitos ou não (CUNHA, 2000). Tudo isso pode ser aplicado ao Legislativo eletrônico, caracterizando assim o e-Legislativo.

Ao abordar a presença da accountability em portais de governos estaduais e municipais no Brasil, Pinho (2006) constata que os avanços, no tocante à accountability, ainda são modestos. O que se observa é que os portais ainda não fazem uso das tecnologias de informação e comunicação para promover interatividade com a sociedade, sendo a ideia de interatividade e de exploração do potencial da comunicação ainda praticamente inexistente.

Ribeiro Filho, Campelo e Araújo (2005) entendem que o governo eletrônico, em todas as suas formas, tem um grande potencial de disseminação de informações, exercendo um papel importante no processo de accountability. Surge como um moderno instrumento de transparência, de responsabilidade social e de prestação de contas, proporcionando à sociedade um meio rápido e eficiente de controle dos resultados do governo.

Independentemente do poder e da esfera governamental, há concordância quanto às possibilidades de aumento da participação da sociedade civil com a implementação do governo eletrônico. Ainda que existam iniciativas de construção de portais no Legislativo, essa esfera do poder não tem atraído o interesse de pesquisadores na mesma proporção da verificada em relação aos portais do Executivo (KERBAUY, 2005).

Nesse contexto, cabe destacar a iniciativa do Senado Federal que, em parceria com o Banco Interamericano de Desenvolvimento (BID), criou o Programa Interlegis para modernizar e integrar o Poder Legislativo nos seus níveis federal, estadual e municipal e promover uma maior transparência e interação entre esse poder e a sociedade. Os meios utilizados são as novas tecnologias de informação (Internet, videoconferência e transmissão de dados), que permitem a comunicação e a troca de experiências entre as casas legislativas e os legisladores e entre o Poder Legislativo e o público, visando aumentar a participação da população no processo legislativo. Pela Internet, é disponibilizado um portal modelo para casas legislativas associadas, no qual é oferecido, como o próprio nome revela, um modelo de portal para os legislativos de diferentes esferas. Por meio do Legislativo eletrônico, as casas legislativas podem veicular diversos tipos de conteúdo na Internet, aumentando a transparência de suas atividades e a interação com a sociedade. Mais de 3 mil 
câmaras municipais já receberam computadores e impressoras do programa para se ligarem à Internet, usarem o correio eletrônico e colocarem suas informações à disposição dos internautas. Essas ações preencheriam um vazio, desempenhando, por assim dizer, uma política de inclusão digital dos poderes legislativos.

\section{Legislativo municipal}

O Poder Legislativo Municipal, representado e exercido pela Câmara Municipal, é o órgão responsável por estabelecer parte das regras para a administração do Executivo e tem como agente legalmente investido de função o vereador. Uma Câmara Municipal, juntamente com seus agentes políticos, órgãos e serviços auxiliares, exerce papel fundamental na integração do cidadão com o Executivo e com os serviços públicos, uma vez que ela não executa tais serviços, mas estabelece regras para a administração deste poder (MEIRELLES, 1988). Para Santana (1995), o Poder Legislativo deve ser atuante em sua função, pois é o representante do povo, devendo cuidar dos interesses dos cidadãos da sua cidade, bem como elaborar leis que os representem. A Câmara Municipal é, em tese, absolutamente independente do Poder Executivo, não havendo em relação a este qualquer submissão.

As duas principais funções do Legislativo são: a regulação da vida social e a fiscalização do Executivo. Os interesses dos diferentes segmentos sociais encontram uma via de harmonia na elaboração de normas que permitem a vida coletiva. Esses interesses são representados por agentes políticos que defenderão o segmento social. Torna-se necessária a busca de uma harmonia social por meio da celebração de pactos, tão consensuais quanto possível, que atendam os interesses conflitantes. A formulação, a condução e a aprovação desses pactos, concretizados na forma de leis, não podem ser feitos diretamente por todos os componentes de cada segmento. É exercida através de representantes que adquiram seu mandato a partir de eleições, a fim de defender o interesse de seus mandantes (WHITAKER, 1992). Assim, é de se esperar que, em tese, os mandantes acompanhem os passos dos seus representantes escolhidos e que, nesse sentido, os portais do Legislativo sejam um poderoso instrumento esclarecedor dessa atuação.

Couto e Abrucio (1995) entendem que, apesar das condições institucionais do funcionamento do Legislativo terem sido modificadas pela Constituição Federal de 1988, devolvendo aos parlamentares várias prerrogativas que lhes tinham sido retiradas pelo regime militar, não foram criados incentivos para que os parlamentares tenham um comportamento propositivo em seu relacionamento com o Executivo.

Apesar de o Legislativo representar um foro de decisões políticas nos interstícios eleitorais - ainda que essa importância seja mais visível na lei do que na concretude do jogo político -, os debates acadêmicos e os mecanismos de controle e de participação social estão majoritariamente voltados para o Executivo, como atestam os conselhos gestores de políticas públicas e a experiência do orçamento participativo (ZANI, 2009).

Toda essa realidade acaba se abatendo sobre a pesquisa no campo legislativo. Os poucos estudos realizados sobre o Legislativo municipal apontam para a manutenção de suas características seculares, relacionadas à baixa capacidade de legislar e a uma atuação fraca diante de um Executivo forte. Vários fatores internos e externos serviriam para explicar essa atuação, que não sofreu alterações apesar de mudanças nos arranjos institucionais locais, no aumento da circulação da informação e na criação de mecanismos de interlocução com a sociedade civil (KERBAUY, 2005). Os membros do Legislativo não se sentem responsáveis pela formulação da política nacional e dedicam-se primordialmente à representação de interesses regionais, corporativos ou clientelísticos (MORAES, 2001).

Apesar das funções já citadas e que devem fazer parte do cotidiano dos vereadores, Joffre Neto (2003) entende que há uma confusão com as funções do prefeito. $\mathrm{O}$ vereador anseia ser um miniprefeito e pretende realizar obras, desembaraçar casos, empregar amigos e necessitados. Contudo, tentando desempenhar o papel de miniprefeito sem miniprefeitura, sem máquina administrativa e sem verbas, logo se sente na necessidade de 
aproximar-se do prefeito (de verdade). Por outro lado, o Executivo é obrigado a recorrer às atribuições específicas do Legislativo, pois governar implica a aprovação de leis de toda ordem: administrativas e, principalmente, orçamentárias. Obviamente, o Executivo procura ver-se livre de controles externos.

Esse jogo de troca de favores é característica constante nas relações entre o Legislativo e o Executivo de muitos municípios brasileiros. Nessa tentativa de adquirir recursos políticos, o vereador passa a uma relação de colaboração crescente com o Executivo. Naturalmente que este exigirá cada vez mais um comportamento colaborativo e obediente, até se chegar a uma posição de mando inconteste. Tendo o Executivo um poder equipotente, o Legislativo se transforma em poder subserviente. Esse cenário configura uma especificidade do governo local: um Executivo forte e um Legislativo fraco.

É comum na literatura política brasileira ressaltar as limitações do Poder Legislativo municipal, no que tange às possibilidades de tomada de decisões políticas, principalmente, à baixa capacidade de legislar das câmaras municipais, que ficam amarradas às prerrogativas legais estabelecidas pela Lei Orgânica dos Municípios. Isso impossibilita o Legislativo municipal de elaborar leis que envolvam gastos, enquanto se garante ao Executivo a primazia incontestável no processo decisório. Portanto, são mínimas as atribuições legislativas das câmaras, em face da possibilidade quase ilimitada do Executivo comandar o processo decisório. A prerrogativa de legislar do Executivo, regulamentada por lei, é a evidência mais clara da perda das funções clássicas do órgão Legislativo (KERBAUY, 2005).

A obtenção de maioria na Câmara é uma condição necessária, porém, insuficiente para que o prefeito aprove as medidas que pretenda implementar. Se os parlamentares sofrerem uma pressão muito grande de suas bases no sentido de vetar determinada política, dificilmente, essa política logrará êxito. Por isso, torna-se necessária também a institucionalização de formas de negociação que incorporem diretamente à discussão os setores a serem atingidos pelas políticas municipais, não apenas para que não ocorra o seu veto às políticas de incremento tributário, mas também para incorporar sua contribuição à designação e à formulação das políticas públicas que serão encampadas pelo município (ABRUCIO; COUTO, 1996).

Há um alheamento dos legislativos de suas funções constitucionais de legislar e fiscalizar o Executivo e uma concordância tácita das câmaras em se subordinarem à prefeitura. Culturalmente, a população e grande parte dos próprios vereadores consideram o Legislativo como auxiliar do Executivo e, portanto, dispensado de suas funções constitucionais de legislar e fiscalizar (JOFFRE NETO, 2003).

O processo decisório no âmbito municipal se configura, nas pequenas e médias cidades, bastante centralizado no Poder Executivo e na consequente fraqueza do Legislativo; uma forma de "executivismo" (ultrapresidencialismo), similar ao que ocorre nos governos estaduais. Já nas capitais e nas grandes cidades, ao mesmo tempo em que não há esse ultrapresidencialismo, o Parlamento também não tem grande poder de veto, diferente do que ocorre no Congresso Nacional (COUTO; ABRUCIO, 1995).

A hipertrofia do Executivo não ocorre nas capitais e nas grandes cidades por três motivos:

primeiro, em comparação com as pequenas cidades, pela maior complexidade social, típica dos grandes conglomerados urbanos, traduzida num aumento dos conflitos de interesses capazes de se articular com maior autonomia perante o poder público;

segundo, em comparação com o poder estadual, devido a uma maior visibilidade das políticas municipais diante dos cidadãos, seja porque as competências são mais visíveis e tangíveis para a população, seja em razão da maior proximidade entre governantes e governados, o que aumenta a importância da Câmara no processamento da demandas; e

terceiro, pelo fato dos vereadores não contarem, como os deputados estaduais, com concorrentes pela destinação de recursos públicos, pois o prefeito não terá, fora do âmbito da Câmara Municipal, outras 
lideranças com poder político-institucional efetivo com as quais possa negociar no sentido de pressionar os parlamentares (Idem, 1995).

A centralidade do Poder Legislativo no processo decisório municipal é definida por fatores estruturais que atuam em dois sentidos opostos. Alguns tendem a colocar o Parlamento numa posição de destaque no sistema político (fatores estruturais positivos). Outros promovem certo grau de dependência do Legislativo em relação ao Executivo (fatores estruturais negativos). São fatores que contribuem para uma maior centralidade as mudanças institucionais impulsionadas pela nova legislação, a proximidade do Legislativo municipal com os cidadãos e o fato de que o prefeito, para governar, depende do Legislativo em maior medida do que o Executivo estadual. Os fatores que contribuem negativamente correspondem às estratégias de negociação que irão mediar a relação entre os dois poderes e às deficiências internas que limitam sua atuação. Os fatores estruturais se conjugam com outros (conjunturais), que por sua vez dizem respeito às condições específicas de cada gestão e de cada legislatura correspondente na determinação do fenômeno analisado (PRALON; FERREIRA, 1998).

Amorim Neto e Tafner (2002) afirmam que o Poder Legislativo brasileiro é extremamente fragmentado, operado por partidos que, em sua maioria, são indisciplinados e cuja principal motivação seria o atendimento de demandas paroquiais. A fragmentação, a indisciplina e o paroquialismo dos partidos concorreriam para tornar o processo de formação de maiorias legislativas extremamente difícil, lento e custoso.

A solução para parcela dessas questões, segundo Farah (2006), está na dimensão democrática dos governos locais. As experiências inovadoras no combate aos problemas desse contexto, como a inversão de prioridades na aplicação e otimização dos recursos públicos, demonstrando preocupação com a transparência administrativa e com o acesso de informações aos seus cidadãos, seriam uma nova forma de gestão compromissada.

Miguel (2003) explicita que, contrariamente ao movimento em que regimes autoritários e totalitários de todo o mundo cederam lugar a democracias eleitorais, ocorrido nos últimos 30 anos concomitante ocorre outro processo: a deterioração da adesão popular às instituições representativas. Observa-se uma crise do sentimento de estar representado, que compromete os laços que idealmente deveriam ligar os eleitores a parlamentares, candidatos, partidos e, de forma mais genérica, aos poderes constitucionais. A constatação desse fenômeno, que ocorre em geral nas democracias ocidentais, ganha tintas mais fortes quando se agregam as condições históricas, antes rascunhadas, da democracia brasileira.

Notadamente em relação ao Legislativo municipal brasileiro, há um aspecto importante que é a sua relação com o Executivo municipal. Tal relação só pode ser devidamente compreendida após a análise da importância que o atendimento às demandas dos eleitores assume na atividade política cotidiana dos vereadores. A maior parte das demandas que o vereador recebe tem sua solução condicionada ao atendimento por parte do Executivo e de suas secretarias. $\mathrm{O}$ vereador é permanentemente confrontado com uma escolha, que confere inteligibilidade à dinâmica relacional entre Executivo e Legislativo: apoiar o governo e o prefeito e ter maior possibilidade deles corresponderem aos seus interesses ou ser oposição e ter sua capacidade de atendimento cerceada (LOPEZ, 2004).

A vereança, assumindo o papel de atendente das necessidades individuais privadas, faz emergir uma relação de clientela, criando, assim, uma relação público-privado que passa pela forma como se estabelece o controle sobre recursos políticos. O que distingue o vereador do tradicional coronel não é necessariamente sua posição na estrutura econômica, que lhe propicia fazer favores, mas essencialmente ter privilégios como homem público; ou seja, é a condição de vereador que lhe permite exercer influência tanto em órgãos públicos quanto nas instituições privadas. No exercício da vereança, cria vínculos, obrigações que lhe facilitam a prática do favor. Do seu desempenho na manutenção dos vínculos dependerá seu sucesso como vereador e sua reeleição (KERBAUY, 1993). 
Especialmente na relação entre os agentes políticos e os eleitores, o mundo público das leis impessoais e universais é constantemente confrontado com a necessidade de burlá-lo para atender às demandas do universo privado dos parentes, dos amigos, dos apadrinhados, dos aliados. Há nos eleitores a percepção de que, se por um lado, o atendimento às demandas depende do acesso do vereador à administração municipal, por outro, $o$ fato mesmo de tornar-se vereador, estar no cargo é, em si, um atributo que lhe confere parte dos acessos (Idem, 2004). Ter acesso é o que diferencia os políticos e, em especial, os vereadores, das demais pessoas. O acesso é um bem escasso e que não pode ser comprado, mesmo por quem tem muito dinheiro. Para se obter acesso, é preciso entrar para a política (KUSCHNIR, 1998).

Uma característica que merece destaque é a existência de redes de relações pessoais construídas dentro de setores da administração pública, entre vereadores e funcionários públicos, que representam uma importante estratégia na maximização da capacidade de atendimento. Nessas relações, a assimetria de poder (econômico ou político), prestígio ou status instaura a dependência pessoal. A assimetria é a base de sustentação das relações de patronagem, pois a relação estabelecida - mesmo sendo de ajuda recíproca - apresenta desigualdade nos termos da troca, permitindo a uma das partes a subordinação da outra, sob pena de suspensão dos benefícios concedidos. Muitas vezes, a indicação de pessoas para empregos públicos atende ao interesse do vereador em facilitar o seu acesso a um setor administrativo específico. Mesmo havendo reciprocidade, pois o vereador concede o emprego e o funcionário, as benesses públicas, há uma inegável assimetria de poder, fundada na dependência do funcionário em relação ao vereador, que é o responsável pela manutenção do emprego do funcionário (LOPEZ, 2004).

A falta de capacidade do Legislativo de fiscalizar o Executivo expressa-se, entre outros aspectos, na dependência dos vereadores em relação à capacidade de atendimento às suas demandas, feitas pelos eleitores, no que dependem do Executivo. O desempenho do papel de fiscalizador garante ao vereador uma ascendência sobre a população. Em relação ao Executivo ocorre exatamente o contrário. Manter e alimentar a relação com o Poder Executivo é o que garante ao seu papel de vereador o prestígio, junto aos eleitores, de agente da mediação (KUSCHNIR, 1993). É nesse contexto de relativo baixo poder do Legislativo, mais acentuado em municipalidades pequenas, ocupando-se preferencialmente de questões paroquiais, que o artigo busca investigar a construção da accountability nos portais eletrônicos de câmaras municipais. Em especial, indaga que interesse o Legislativo municipal teria em construir portais accountables diante do quadro descrito, no qual se constata uma sociedade civil passiva.

\section{Métodos e procedimentos}

A pesquisa realizada para investigar as condições de construção da accountability nos portais eletrônicos de câmaras municipais é de cunho avaliativo e exploratório, realizada por meio de estudo de casos múltiplos, com abordagem predominantemente qualitativa.

A escolha do estudo de casos múltiplos como método diz respeito à possibilidade de exploração do caso (ou múltiplos casos) envolvendo coleta de dados em profundidade (CRESWELL, 1997). Além disso, segundo Stake (1995), esse método permite a comparação dos casos analisados.

Na primeira etapa para identificar câmaras municipais catarinenses com portal eletrônico, foi feita uma consulta ao portal do governo do estado de Santa Catarina (http://www.sc.gov.br). Nessa consulta, realizada em 19 de janeiro de 2009, foram identificadas 37 câmaras municipais com portal eletrônico. Atentando para um número reduzido de portais, considerando o total de municípios do estado, partiu-se para uma segunda etapa com o objetivo de identificar outras câmaras com portal eletrônico, não listadas no portal do governo catarinense. Assim, fez-se uma busca no site Google (http://www.google.com.br), nos dias 20 e 21 de janeiro de 2009, quando foram identificadas outras 63 câmaras municipais catarinenses com portal eletrônico. 
Na definição da amostra, foram selecionados os portais eletrônicos de câmaras de municípios com população acima de 50.000 habitantes. O pressuposto foi o de que, pelo porte populacional, esses municípios teriam suas câmaras com maiores condições de construir portais mais desenvolvidos, contemplando, inclusive, o quesito accountability. Os portais analisados, com os respectivos endereços eletrônicos, são apresentados no quadro 1:

\section{Quadro 1 - Portais analisados com respectivos endereços eletrônicos}

\begin{tabular}{|l|l|l|}
\hline$N^{\mathbf{o}}$ & Câmaras Municipais & Endereços dos Portais \\
\hline 01 & Câmara Municipal de Balneário Camboriú & http://www.cambc.sc.gov.br \\
\hline 02 & Câmara Municipal de Blumenau & http://www.camarablu.sc.gov.br \\
\hline 03 & Câmara Municipal de Brusque & http://camarabrusque.sc.gov.br \\
\hline 04 & Câmara Municipal de Caçador & http://www.camaracacador.sc.gob.br \\
\hline 05 & Câmara Municipal de Chapecó & http://www.cmc.sc.gov.br \\
\hline 06 & Câmara Municipal de Concórdia & http://www.cvc.sc.gov.br \\
\hline 07 & Câmara Municipal de Criciúma & http://www.camcri.sccom.br \\
\hline 08 & Câmara Municipal de Florianópolis & http://www.cmf.sc.gov.br \\
\hline 09 & Câmara Municipal de Itajaí & http://www.cvi.sc.gov.br \\
\hline 10 & Câmara Municipal de Jaraguá do Sul & http.//www.cmjs.sc.gov.br \\
\hline 11 & Câmara Municipal de Joinville & http://www.cvj.sc.gov.br \\
\hline 13 & Câmara Municipal de Lages & http://www.camaralages.sc.gov.br \\
\hline 14 & Câmara Municipal de Mafra & http://www.camaramafra.sc.gov.br \\
\hline 15 & Câmara Municipal de Palhoça & http://www.cmp.sc.gov.br \\
\hline 16 & Câmara Municipal de Rio do Sul & http://www.camariodosul.sc.gov.br \\
\hline 17 & Câmara Municipal de São Bento do Sul & http://www.cmsbs.sc.gov.br \\
\hline 18 & Câmara Municipal de São José Tubarão & http://www.cmsj.sc.gov.br \\
\hline
\end{tabular}

Fonte: elaborado pelos autores.

Para tanto, foi construído um modelo de análise com três dimensões da accountability: prestação de contas, transparência e participação/interação, conforme apresentado no quadro 2.

O modelo foi construído a partir de experiências anteriores de diversos autores e instituições (AKUTSU, 2002; AKUTSU; PINHO, 2002; DINIZ, 2000; MORAES, 2004; PRADO, 2004). Para cada dimensão, foram agrupados indicadores em três categorias: baixa capacidade, média capacidade e alta capacidade. Observando a ocorrência ou não desses indicadores nos portais, procurou-se detectar a baixa, média ou alta capacidade dos portais em criar condições para a prestação de contas e para que haja transparência e participação/interação. Cada estrato de capacidade se constitui a partir do atendimento de determinadas ofertas de serviços públicos.

A partir do modelo de análise, foi elaborado um protocolo de observação para coletar os dados disponíveis nos portais eletrônicos mantidos pelas câmaras municipais. O protocolo de observação, segundo Creswell (2007), é utilizado para registrar dados de observações múltiplas durante a realização de um estudo qualitativo. Os indicadores foram agrupados de acordo com as dimensões consideradas, conforme modelo de análise apresentado no quadro 1. Seguindo-se os itens do protocolo, foram feitas as visitas aos portais eletrônicos e anotadas as informações disponíveis. 
Quadro 2 - Modelo de análise

\begin{tabular}{|c|c|}
\hline \multicolumn{2}{|c|}{ Prestação de Contas } \\
\hline Capacidade & INDICADORES \\
\hline Baixa & Divulgação parcial e/ou fora do prazo do conjunto de relatórios legais \\
\hline \multirow{2}{*}{ Média } & Divulgação do conjunto de relatórios legais no prazo \\
\hline & Divulgação parcial do conjunto de relatórios legais em versões simplificadas \\
\hline \multirow{2}{*}{ Alta } & Divulgação do conjunto de relatórios legais em versões simplificadas \\
\hline & Divulgação de relatórios gerenciais dos gastos incorridos \\
\hline \multicolumn{2}{|c|}{ Transparência } \\
\hline Capacidade & INDICADORES \\
\hline \multirow{4}{*}{ Baixa } & Informações institucionais \\
\hline & Notícias \\
\hline & Informações gerais \\
\hline & Legislação \\
\hline \multirow{5}{*}{ Média } & Ferramenta de busca \\
\hline & Download de documentos, textos, relatórios \\
\hline & Mapa do site \\
\hline & Links para os setores \\
\hline & Links para outros sites \\
\hline \multirow{5}{*}{ Alta } & Vídeos explicativos \\
\hline & Vídeos das sessões \\
\hline & Divulgação da tramitação das diferentes matérias \\
\hline & Seção de atos públicos \\
\hline & Divulgação de planos e ações \\
\hline \multicolumn{2}{|c|}{ Participação/Interação } \\
\hline Capacidade & INDICADORES \\
\hline \multirow{3}{*}{ Baixa } & Endereço de e-mail \\
\hline & Telefones \\
\hline & Formulários eletrônicos \\
\hline \multirow{2}{*}{ Média } & Indicação de análise dos e-mails recebidos \\
\hline & Monitoramento das ações dos usuários \\
\hline \multirow{4}{*}{ Alta } & Ouvidoria \\
\hline & Resposta aos e-mails recebidos \\
\hline & Chats individuais e/ou coletivos \\
\hline & Blog para debate \\
\hline
\end{tabular}

Fonte: elaborado pelos autores.

\section{Caso empírico}

O estado de Santa Catarina divide-se em 293 municípios e não apresenta grandes concentrações populacionais. Distribuídas uniformemente, as cidades são majoritariamente de pequeno e médio porte. Do total de municípios, apenas 20 tem mais de 50.000 habitantes. Mesmo Florianópolis, distingue-se das outras capitais brasileiras por não apresentar grande concentração populacional, o que confere ao estado uma singularidade. Na faixa de 50.001 a 100.000 habitantes estão os municípios de Araranguá, Balneário Camboriú, Brusque, 
Caçador, Canoinhas, Concórdia, Mafra, Rio do Sul, São Bento do Sul e Tubarão. Na faixa de 100.001 a 200.000 habitantes estão os municípios de Chapecó, Criciúma, Itajaí, Jaraguá do Sul, Lages, Palhoça e São José. Os municípios de Blumenau, Florianópolis e Joinville têm população acima de 200.000 habitantes.

O acesso aos portais eletrônicos foi realizado nos dias 9, 10 e 11 de julho de 2009. Nesse período, o portal eletrônico da Câmara Municipal de Palhoça estava em reconstrução e o da Câmara Municipal de Canoinhas constava como servidor não encontrado. Portanto, desistiu-se de analisar esses dois portais.

\section{Resultados: análise e crítica}

Os resultados das observações, apresentados na sequência, são sumarizados segundo cada dimensão da accountability construída no modelo teórico.

Prestação de contas

A ocorrência dos indicadores de prestação de contas nos portais selecionados é sintetizada no quadro 3 .

Quadro 3 - Ocorrência dos indicadores de prestação de contas nos portais selecionados

\begin{tabular}{|c|c|c|c|c|c|c|c|c|c|c|c|c|c|c|c|}
\hline Indicadores & 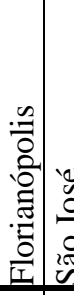 & 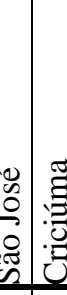 & 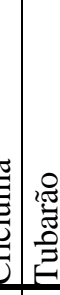 & 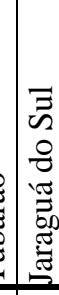 & 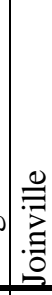 & $\sum^{\pi}$ & 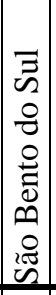 & 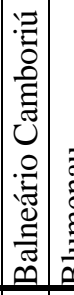 & : & . & 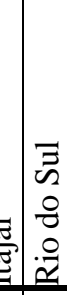 & & & & \\
\hline $\begin{array}{l}\text { Divulgação parcial e/ou fora de prazo do conjunto } \\
\text { de relatórios legais }\end{array}$ & $x$ & $\mathrm{X}$ & $\mathrm{X}$ & $\mathrm{X}$ & $\mathrm{X}$ & & $\mathrm{X}$ & \begin{tabular}{|l|l}
$\mathrm{X}$ & $\mathrm{X}$ \\
\end{tabular} & $\begin{array}{lll}x & x\end{array}$ & $\mathrm{x}$ & $\mathrm{X}$ & & $\mathrm{X}$ & & $\mathrm{X}$ \\
\hline $\begin{array}{l}\text { Divulgação do conjunto de relatórios legais no } \\
\text { prazo }\end{array}$ & & & & & & & & & & & & & & & \\
\hline $\begin{array}{l}\text { Divulgação parcial do conjunto de relatórios } \\
\text { legais em versões simplificadas }\end{array}$ & & & & & & & $\mathrm{X}$ & & & & & & & & \\
\hline $\begin{array}{l}\text { Divulgação do conjunto de relatórios legais em } \\
\text { versões simplificadas }\end{array}$ & & & & & & & & & & & & & & & \\
\hline $\begin{array}{l}\text { Divulgação de relatórios gerenciais dos gastos } \\
\text { incorridos }\end{array}$ & & & $\mathrm{X}$ & & & & & & & & & & & & \\
\hline
\end{tabular}

Fonte: elaborado pelos autores.

Como pode ser observado no quadro 3, a maioria das câmaras municipais presta contas dos relatórios de Gestão Fiscal (RGFs) de forma parcial e fora do prazo legal em seus portais. Entre os RGFs, o demonstrativo da despesa com pessoal é o mais recorrente, além dos balancetes financeiros mensais. No portal da Câmara Municipal de São Bento do Sul é disponibilizado o roteiro detalhado das viagens feitas por vereadores e funcionários e das diárias concedidas, tanto no exercício atual quanto no anterior, o que pode representar uma forma de RGF simplificado. Na maioria das vezes, constata-se uma média capacidade dos portais eletrônicos de promover condições para o processo de prestação de contas.

Todavia, há portais em que não é publicado qualquer tipo de demonstrativo ou é impossível localizar algum. É o caso dos portais das câmaras de Chapecó, Itajaí, Lages, Mafra e de São José, nos quais fica evidente a baixa capacidade de prestação de contas. No portal da Câmara de Mafra, por exemplo, há um link para o orçamento 
mensal do exercício atual e de exercícios anteriores, mas, ao tentar fazer o download do documento, aparece a mensagem "Nenhum arquivo encontrado".

Duas câmaras, a de Florianópolis e a de São José, divulgam relatórios de execução do cronograma de ações do Legislativo. Nesse sentido, deve ser destacado o portal da Câmara de Florianópolis, que publica um relatório denominado Plano de Metas. Esse relatório descreve as atividades previstas para três programas - Programa de Controle de Custos, Programa de Controle e Acessibilidade e Programa de Modernização Institucional -, indicando o estágio/fase em que cada uma se encontra: planejada, em execução ou executada. Além disso, a Câmara de Florianópolis publica relatórios de execução orçamentária de exercícios anteriores. Entretanto, ainda que esses dois casos representem um avanço, em nenhum portal foi observada divulgação dentro do prazo.

Se considerarmos que os portais eletrônicos tendem a uma média capacidade de prestação de contas, percebe-se que o conjunto de Legislativos locais, objeto de estudo, pode estar dispensando importância a essa dimensão da accountability, mesmo que esta pesquisa não tenha analisado o conteúdo nem a linguagem adotada sobre os relatórios integrantes do processo de prestação de contas. Indicariam atribuir maior importância ainda caso divulgassem, mesmo parcialmente, o RGFs na versão simplificada, o que só foi observado em apenas um portal.

Os RGFs são elaborados a partir de uma linguagem técnica e específica empregada na contabilidade governamental, de entendimento normalmente restrito aos profissionais da área. A partir do cenário observado, fica a dúvida: Os relatórios são divulgados espontaneamente, numa iniciativa do Legislativo local para promover a prestação de contas por meio do portal eletrônico, ou essa publicidade atende à norma legal que exige alguma estratégia de divulgação?

O processo de prestação de contas relaciona-se, principalmente, à publicidade quanto à origem e à utilização dos recursos públicos. Sua efetivação é essencial para o exercício da accountability. Contudo, isso não parece ser a realidade dos portais observados, nos quais a divulgação dos relatórios ocorre normalmente de forma parcial e/ou fora do prazo legal. Se os RGFs não são publicados integralmente e dentro do prazo legal, mesmo havendo sanções legais pelo descumprimento dessas exigências, estamos distantes de uma situação em que a sociedade civil poderá acessar, por meio dos portais eletrônicos, a essência da prestação de contas e exigir a responsabilização pelos gastos públicos. Em outras palavras, não se nota uma predisposição a cumprir esse requisito fundamental da accountability.

\section{Transparência}

Os indicadores de transparência e as respectivas ocorrências nos portais selecionados são resumidos no quadro 4.

Como mostra o quadro 4, na sua maioria, os portais eletrônicos selecionados apresentam alta capacidade para promover a transparência dos atos públicos. Dos indicadores utilizados para mensurar essa dimensão da accountability, apenas o indicador Link para os setores não foi identificado em nenhum portal. Por outro lado, há extremos em termos de capacidade, como os portais das câmaras de Mafra e de Rio do Sul, que apresentam um número reduzido de indicadores, até a Câmara de Florianópolis, que apresenta praticamente todos os indicadores. 


\section{Quadro 4 - Ocorrência dos indicadores de transparência nos portais selecionados}

\begin{tabular}{|c|c|c|c|c|c|c|c|c|c|c|c|c|c|c|c|c|c|}
\hline Indicadores & 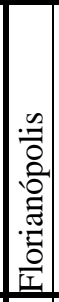 & $\begin{array}{r} \\
0 \\
0 \\
0 \\
0 \\
2 \\
2 \\
0 \\
0\end{array}$ & 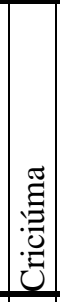 & 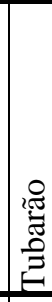 & 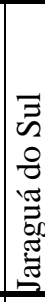 & & & 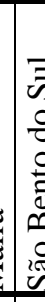 & 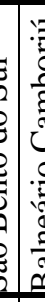 & $\frac{\vec{Z}}{\tilde{\Xi}}$ & 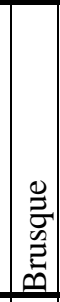 & & 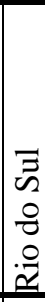 & \begin{tabular}{|l} 
\\
\\
$\widetilde{\Xi}$ \\
$\stackrel{5}{5}$ \\
$\stackrel{5}{=}$ \\
\end{tabular} & 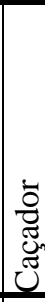 & & 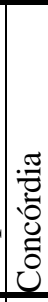 \\
\hline Informações institucionais & $\mathrm{x}$ & & $\mathrm{x}$ & $\mathrm{x}$ & $\mathrm{X}$ & $\mathrm{x}$ & $\mathrm{X}$ & $\mathrm{x}$ & $\mathrm{x}$ & $\mathrm{x}$ & $\mathrm{x}$ & $\mathrm{x}$ & $\mathrm{x}$ & $\mathrm{x}$ & $\mathrm{x}$ & $\mathrm{x}$ & $\mathrm{X}$ \\
\hline Notícias & $\mathrm{x}$ & $\mathrm{x}$ & $\mathrm{x}$ & $\mathrm{x}$ & $\mathrm{x}$ & $\mathrm{x}$ & $\mathrm{x}$ & $\mathrm{x}$ & $\mathrm{x}$ & $\mathrm{x}$ & $\mathrm{x}$ & $\mathrm{X}$ & $\mathrm{x}$ & $\mathrm{X}$ & $\mathrm{x}$ & $\mathrm{X}$ & $\mathrm{x}$ \\
\hline Informações gerais & $\mathrm{x}$ & $\mathrm{x}$ & $\mathrm{x}$ & $\mathrm{X}$ & & & $\mathrm{x}$ & $\mathrm{x}$ & & & $\mathrm{x}$ & & & & & $\mathrm{X}$ & \\
\hline Legislação & $\mathrm{x}$ & $\mathrm{x}$ & $\mathrm{x}$ & $\mathrm{X}$ & & $\mathrm{X}$ & $\mathrm{x}$ & $\mathrm{x}$ & $\mathrm{x}$ & $\mathrm{x}$ & $\mathrm{x}$ & $\mathrm{X}$ & & $\mathrm{X}$ & $\mathrm{x}$ & $\mathrm{X}$ & $\mathrm{x}$ \\
\hline Ferramenta de busca & $\mathrm{x}$ & $\mathrm{x}$ & & & $\mathrm{x}$ & $\mathrm{x}$ & & & & & & & & & $\mathrm{x}$ & & $\mathrm{x}$ \\
\hline Download de documentos, textos e relatórios & $\mathrm{X}$ & $\mathrm{x}$ & $\mathrm{X}$ & $\mathrm{x}$ & $\mathrm{x}$ & $\mathrm{x}$ & $\mathrm{x}$ & & $\mathrm{x}$ & $\mathrm{x}$ & $\mathrm{x}$ & $\mathrm{x}$ & $\mathrm{x}$ & $\mathrm{x}$ & $\mathrm{x}$ & $\mathrm{x}$ & $\mathrm{x}$ \\
\hline Mapa do site & $\mathrm{x}$ & $\mathrm{x}$ & & & & & & & & & & & & & & & $\mathrm{X}$ \\
\hline Links para os setores & & & & & & & & & & & & & & & & & \\
\hline Links para outros sites & $\mathrm{x}$ & & $\mathrm{x}$ & $\mathrm{x}$ & $\mathrm{X}$ & $\mathrm{x}$ & & & $\mathrm{x}$ & $\mathrm{x}$ & $\mathrm{x}$ & $\mathrm{X}$ & $\mathrm{x}$ & $\mathrm{X}$ & & $\mathrm{X}$ & \\
\hline Vídeos explicativos & & & & & & & & & & $\mathrm{x}$ & & $\mathrm{x}$ & $\mathrm{x}$ & & & & \\
\hline Vídeos das sessões & $\mathrm{x}$ & $\mathrm{x}$ & $\mathrm{x}$ & $\mathrm{x}$ & $\mathrm{x}$ & $\mathrm{x}$ & & & $\mathrm{x}$ & $\mathrm{x}$ & & $\mathrm{x}$ & & $\mathrm{X}$ & & & \\
\hline Divulgação da tramitação das diferentes matérias & $\mathrm{x}$ & $\mathrm{x}$ & & $\mathrm{x}$ & $\mathrm{x}$ & $\mathrm{x}$ & $\mathrm{x}$ & $\mathrm{x}$ & $\mathrm{x}$ & $\mathrm{x}$ & $\mathrm{x}$ & & & & $\mathrm{x}$ & $\mathrm{X}$ & \\
\hline Seção de atos públicos & $\mathrm{x}$ & $\mathrm{x}$ & $\mathrm{x}$ & $\mathrm{x}$ & & $\mathrm{x}$ & $\mathrm{x}$ & $\mathrm{x}$ & $\mathrm{x}$ & $\mathrm{x}$ & $\mathrm{x}$ & $\mathrm{x}$ & $\mathrm{x}$ & $\mathrm{x}$ & $\mathrm{x}$ & $\mathrm{x}$ & $\mathrm{X}$ \\
\hline Divulgação de planos e ações & $\mathrm{x}$ & & & & & & & & & & & & & & & & \\
\hline
\end{tabular}

Fonte: elaborado pelos autores.

O indicador Informações institucionais não foi identificado apenas na Câmara de São José. As informações veiculadas, normalmente, referem-se ao histórico da câmara, composição de comissões formadas pelos agentes políticos e organogramas. A Câmara de Florianópolis, por exemplo, apresenta uma listagem de todos os servidores (comissionados, chefias, efetivos e estagiários) indicando a lotação, o cargo e o ramal de contato.

Todos os portais observados apresentam Notícias, cujo conteúdo normalmente versa sobre a própria Câmara Municipal. Alguns portais também apresentam links para jornais locais e estaduais. No portal da Câmara de São José, o destaque é para os eventos da própria câmara. Há também arquivos com clipagem de matérias da câmara publicadas em jornais locais, regionais e estaduais. Já o portal da Câmara de Concórdia disponibiliza notícias sobre o Legislativo e também sobre o Executivo. Em relação às Informações gerais, predominam informações sobre o histórico da câmara e do município.

Os portais que apresentam Legislação, normalmente, disponibilizam uma ferramenta de busca, permitindo a procura pelo tipo de legislação, pelo tipo de lei, por palavras-chave e pelo ano. A pesquisa pode ser configurada, escolhendo-se simultaneamente o tipo de ordenamento do documento, o total de documentos por página e a quantidade total de documentos. Cabe ressaltar que a ferramenta de busca de legislações não se confunde com o indicador Ferramenta de busca do próprio portal, disponibilizado por algumas câmaras.

Com exceção do portal da Câmara de São Bento do Sul, todos os demais permitem Download de documentos, textos e relatórios. Do total de portais selecionados, apenas três apresentam Mapa do site e nenhum dos portais disponibiliza Links para os setores da própria câmara. Não obstante, a maioria apresenta Links para outros sites; geralmente, links para outras câmaras e prefeituras do estado, para os poderes Legislativo, Executivo e Judiciário e para outras instituições. Um avanço importante observado refere-se aos vídeos disponibilizados. Parcela representativa dos portais veicula Vídeos das sessões. A Câmara de Florianópolis apresenta, por meio 
do portal, a TV Câmara, com os seguintes programas: A Alma do Artista, Câmara Perfil, Cidade em Debate, Curtas, Escuta Aqui Ó, JC Notícias, O Termo É e Pelas Ruas da Minha Cidade. Os portais das câmaras de São José e de Joinville, além da TV Câmara, apresentam a Rádio Câmara. A TV Câmara de Lages produz o Jornal TV do Legislativo Lageano, bem como os programas Fala Vereador, Saúde na TV, Esporte e Cidadania, Espaço Livre, Judiciário na TV, Câmara Variedades, Semana do Vereador e Vereador na Comunidade. Alguns dos portais observados permitem que as sessões sejam assistidas em tempo real.

A Divulgação da tramitação das diferentes matérias, normalmente, é feita a partir da ferramenta de busca utilizada na procura de legislações. Apenas a Câmara de Jaraguá do Sul não contempla em seu portal uma Seção de atos públicos. A Divulgação de planos e ações é feita exclusivamente pela Câmara de Florianópolis. Aparentemente, a dimensão transparência mostra-se mais ativa que a dimensão prestação de contas no conjunto de portais analisados. Do ponto de vista tecnológico, parece se confirmar o pressuposto de que os municípios com maior população possuem portais dos seus Legislativos mais aperfeiçoados.

Observa-se no quadro 4 a ocorrência de indicadores de transparência dos três estratos de capacidade na maioria dos portais eletrônicos. Disponíveis os indicadores, até que ponto são utilizados para o exercício da transparência? As matérias e vídeos são editados antes da veiculação no portal ou mostram também questões polêmicas e ações duvidosas?

Os achados na pesquisa não são suficientes para se responder a essas indagações. No entanto, existindo os indicadores tal como identificados através do quadro 4, percebe-se que há condições para a construção da transparência. A depender do interesse dos agentes políticos locais, tais indicadores poderão ser utilizados para fins de promoção política e não para o efetivo exercício da transparência.

\section{Participação/interação}

As observações acerca da ocorrência de indicadores de participação/interação nos portais selecionados são compendiadas no quadro 5.

O quadro 5 revela que em todos os portais selecionados constam Endereço de e-mail e Telefone para contato com os munícipes. Somente a Câmara de Blumenau não disponibiliza Formulários eletrônicos. Os demais indicadores foram observados em menor escala, sinalizando uma baixa capacidade dos portais de promover a participação/interação dos cidadãos.

Há portais com um e-mail de contato e e-mails dos vereadores. Outros, os e-mails de apenas uma parcela destes. Há também aqueles com links para a home page pessoal dos vereadores e os que fornecem somente um e-mail geral. O portal da Câmara de Caçador, por exemplo, disponibiliza e-mails de funcionários, de vereadores e um para os vereadores mirins. No que concerne aos números de telefones e formulários, a maioria apresenta apenas um telefone e um formulário geral de contato. Poucos portais disponibilizam telefones e formulários individuais de vereadores e de funcionários.

Em nenhum portal foi percebida qualquer Indicação de análise dos e-mails recebidos. O monitoramento das ações dos usuários, quando existe, é feito através da contagem do número de visitantes ou do número de visitantes on-line. A enquete é, potencialmente, uma forma de monitoramento, sendo observada em cinco portais. Durante o período de observação, as enquetes foram respondidas e os resultados parciais apresentados na sequência. Nos portais que disponibilizam o canal de ouvidoria, esta pode ser contatada por meio de formulário específico ou por telefone. Não foi observada a ocorrência dos seguintes indicadores: Resposta aos e-mails recebidos, Chats individuais elou coletivos e Blog para debate. 
Quadro 5 - Ocorrência dos indicadores de participação/interação nos portais selecionados

\begin{tabular}{|c|c|c|c|c|c|c|c|c|c|c|c|c|c|c|c|c|c|}
\hline Indicadores & 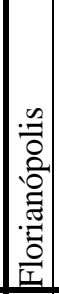 & $\begin{array}{l} \\
0 \\
0 \\
0 \\
0 \\
0 \\
2 \\
2 \\
\end{array}$ & :气 : & 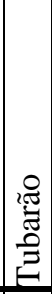 & 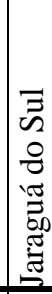 & & 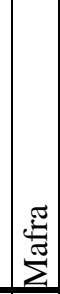 & 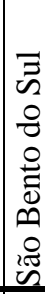 & 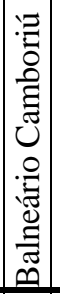 & 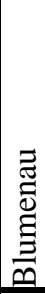 & & & 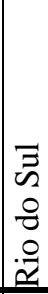 & 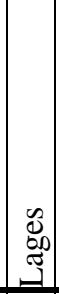 & & & 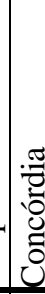 \\
\hline Endereço de e-mail & $\mathrm{x}$ & $\mathrm{x}$ & $\mathrm{x}$ & $\mathrm{X}$ & $\mathrm{x}$ & $\mathrm{x}$ & $\mathrm{x}$ & $\mathrm{x}$ & $\mathrm{X}$ & $\mathrm{x}$ & $\mathrm{x}$ & $\mathrm{x}$ & $\mathrm{x}$ & $\mathrm{x}$ & $\mathrm{x}$ & $\mathrm{x}$ & $\mathrm{x}$ \\
\hline Telefones & $\mathrm{x}$ & $\mathrm{x}$ & $\mathrm{x}$ & $\mathrm{x}$ & $\mathrm{x}$ & $\mathrm{x}$ & $\mathrm{x}$ & $\mathrm{x}$ & $\mathrm{X}$ & $\mathrm{x}$ & $\mathrm{x}$ & $\mathrm{x}$ & $\mathrm{x}$ & $\mathrm{x}$ & $\mathrm{x}$ & $\mathrm{x}$ & $\mathrm{x}$ \\
\hline Formulários eletrônicos & $\mathrm{x}$ & $\mathrm{x}$ & $\mathrm{X}$ & $\mathrm{X}$ & $\mathrm{x}$ & $\mathrm{x}$ & $\mathrm{x}$ & $\mathrm{X}$ & $\mathrm{X}$ & & $\mathrm{X}$ & $\mathrm{X}$ & $\mathrm{x}$ & $\mathrm{x}$ & $\mathrm{X}$ & $\mathrm{x}$ & $\mathrm{x}$ \\
\hline Indicação de análise dos e-mails recebid & & & & & & & & & & & & & & & & & \\
\hline Monitoramento das ações dos usuários & $\mathrm{x}$ & $\mathrm{x}$ & & & & & & & & & & & & & & $\mathrm{x}$ & \\
\hline Ouvidoria & $\mathrm{x}$ & & & & & $\mathrm{x}$ & & & $\mathrm{X}$ & & & & & & & & \\
\hline Resposta aos e-mails recebidos & & & & & & & & & & & & & & & & & \\
\hline Chats individuais e/ou coletivos & & & & & & & & & & & & & & & & & \\
\hline Blog para debate & & & & & & & & & & & & & & & & & \\
\hline
\end{tabular}

Fonte: elaborado pelos autores.

A participação/interação só tem razão de ser quando o participante recebe algum tipo de retorno daquilo que foi sugerido, questionado ou simplesmente identificado. Os endereços de e-mail, telefones para contato e formulários disponibilizados nos portais eletrônicos, conforme observado no quadro 5 , sem a análise e a resposta aos e-mails recebidos, sem um monitoramento das ações de quem participou ou mesmo sem um espaço para debates não contribui para o exercício dessa dimensão da accountability.

A participação/interação mostra-se bastante frágil nos portais analisados, sem condições efetivas de contribuir para a construção da accountability. De certo modo, esses resultados ratificam investigações anteriores (SANTOS, 1993; PINHO, 2008) que apontam a falta de participação política como o verdadeiro calcanhar de Aquiles do processo político brasileiro ou, pelo menos, um dos entraves a esse processo.

A despeito dos resultados alcançados, a baixa capacidade dos portais de promover a participação pode desencadear o que Santos (1993) observa nos cidadãos brasileiros: apatia ou desmotivação. Por sua vez, essa baixa participação dos cidadãos, segundo Pinho (2008) acaba comprometendo a exigência de transparência e de prestação de contas.

\section{Conclusões}

A investigação sobre as condições de construção da accountability em portais eletrônicos de câmaras municipais partiu de um modelo de análise concebido a partir de indicadores de prestação de contas, de transparência e de participação/interação, sendo essas as dimensões da accountability consideradas. Para inferir sobre as condições dos portais eletrônicos, os indicadores de cada dimensão foram agrupados em estratos de capacidade (baixa, média e alta). A opção por câmaras de municípios com mais de 50.000 habitantes partiu do pressuposto de que estas possuem maiores condições de desenvolver os portais eletrônicos, contemplando, inclusive, o quesito accountability.

$\mathrm{Na}$ observação dos indicadores de prestação de contas, a maioria dos indicadores identificados estão nos estratos de baixa e média capacidade. Os demonstrativos são divulgados parcialmente e/ou fora do prazo legal. Em menor proporção, inexiste qualquer tipo de demonstrativo e/ou impossibilidade de sua localização. A ausência de divulgação dos RGFs na forma simplificada, mesmo parcialmente, dificulta o entendimento e a acessibilidade às informações que procuram explicar a gestão dos recursos públicos empreendida. Conclui- 
se que os portais eletrônicos observados não possuem condições para a construção de uma efetiva prestação de contas e, consequentemente, para a construção da accountability a partir dessa dimensão.

Quanto à transparência, a maioria dos portais possui indicadores dos três estratos de capacidade. Esse contexto revela que, de maneira geral, os portais têm condições para a construção da transparência, bem como da accountability, a partir dessa dimensão. Todavia, a ausência de análise do conteúdo dos indicadores, que constitui uma limitação do estudo, não permite inferir se há construção da transparência, apenas, pressupõe a existência de condições para tal.

No tocante à dimensão participação/interação, os indicadores concentram-se no estrato baixa capacidade. A TIC existe. Contudo, não foram observadas características que pudessem indicar que a interatividade realmente ocorra. A participação/interação mostra-se bastante frágil nos portais analisados, sem condições efetivas de contribuir para a construção da accountability. As conclusões deste estudo com câmaras municipais do estado de Santa Catarina corroboram Cunha e Santos (2005), quando estes destacam as restrições ao uso dos meios eletrônicos por parte dos vereadores brasileiros. Conforme a pesquisa de Cunha e Santos, os vereadores têm correio eletrônico, o endereço é divulgado e consegue-se obtê-lo facilmente, mas as mensagens recebidas não são respondidas; algumas, jamais chegam a ser lidas.

No conjunto das observações individualizadas das dimensões, conclui-se que, no estado de Santa Catarina, os portais eletrônicos das câmaras de vereadores de municípios com mais de 50.000 habitantes têm baixa capacidade de viabilizar a construção da accountability. Tal constatação indica a possibilidade de resultados ainda mais desanimadores nos municípios com menos de 50.000 habitantes. Como diz o próprio título deste artigo, a construção da accountability é um processo em marcha na sociedade brasileira. Ainda não é possível afirmar se as forças que pugnam pela democracia irão se sobrepor àquelas que se ancoram no atraso e no conservadorismo.

\section{Referências}

ABRUCIO, Fernando Luiz. Reforma do Estado no federalismo brasileiro: a situação das administrações públicas estaduais. Revista de Administração Pública, Rio de Janeiro, ano 39, n.2, p.401-420, mar./abr. 2005.

; COUTO, Cláudio Gonçalves. A redefinição do papel do Estado no âmbito local. São Paulo em Perspectiva, São Paulo, v.10, n.3, p.40-47, 1996.

AKUTSU, Luiz. Sociedade da informação, accountability e democracia delegativa: investigação em portais de governo no Brasil. 2002. 152f. Dissertação (Mestrado em Administração) - Escola de Administração da Universidade Federal da Bahia, Núcleo de Pós-Graduação em Administração, Universidade Federal da Bahia, Salvador, 2002.

Portais de governo no Brasil: accountability e democracia delegativa. In: CONGRESO INTERNACIONAL DEL CLAD SOBRE LA REFORMA DEL ESTADO Y DE LA ADMINISTRACIÓN PÚBLICA, X, 2005, Santiago. Anais... Buenos Aires: Clad, 2005.

; PINHO, José Antônio Gomes de. Sociedade da informação, accountability e democracia delegativa: investigação em portais de governo no Brasil. Revista de Administração Pública, Rio de Janeiro, ano 36, n.5, p.723-745, set./out. 2002.

AMARAL, Marcelo Santos. Accountability, governo local e democracia: investigação em portais municipais do estado da Bahia. 2007. 133f. Dissertação (Mestrado em Administração) - Escola de Administração da Universidade Federal da Bahia, Núcleo de Pós-Graduação em Administração, Universidade Federal da Bahia, Salvador, 2007. 
AMORIM, Sônia Naves David. Ética na esfera pública: a busca de novas relações Estado/sociedade. Revista do Serviço Público, Brasília, DF, ano 51, n.2, p.94-104, abr./jun. 2000.

AMORIM NETO, O.; TAFNER, P. Governos de coalizão e mecanismos de alarme de incêndio no controle legislativo das medidas provisórias. Dados - Revista de Ciências Sociais, Rio de Janeiro, v.45, n.1, p.5-38, 2002.

BENDIX, Reinhard. Max Weber: um perfil intelectual. Brasília, DF: UnB, 1986.

BRAGA, Lamartine Vieira et al. O papel do governo eletrônico no fortalecimento da governança do setor público. Revista do Serviço Público, Brasília, DF, ano 59, n.1, p.5-21, jan./mar. 2008.

BRASIL. Interlegis: comunidade virtual do Poder Legislativo. Disponível em: <www.interlegis.gov.br>. Acesso em: 18 jun. 2009.

BRESSER-PEREIRA, Luiz Carlos. Cidadania e res publica: a emergência dos direitos republicanos. Revista de Filosofia Política, Porto Alegre, v.1, p.99-144, 1997.

BUARQUE DE HOLANDA, Sergio. Raízes do Brasil. Rio de Janeiro: Livraria José Olympio, 1969.

CAMPOS, Ana Maria. Accountability: quando poderemos traduzi-la para o português? Revista de Administração Pública, Rio de Janeiro, ano 24, n.2, p.30-50, fev./abr. 1990.

CARDOSO, René Fernando. Um estudo sobre os resultados da utilização da bolsa eletrônica de compras no governo do estado de São Paulo. Revista do Serviço Público, Brasília, DF, ano 55, n.4, p.31-44, out./dez. 2004.

CENEVIVA, Ricardo, FARAH, Marta Ferreira Santos. Democracia, avaliação e accountability: a avaliação de políticas públicas como instrumento de controle democrático. In: ENCONTRO DE ADMINISTRAÇÃO PÚBLICA E GOVERNANÇA, II, 2006, São Paulo. Anais... Rio de Janeiro: Anpad, 2006.

COUTO, Cláudio Gonçalves; ABRUCIO, Luiz Fernando. Governando a cidade? A força e a fraqueza da Câmara Municipal. São Paulo em Perspectiva, São Paulo, v.9, n.2, p.57-65, 1995.

CUNHA, Maria Alexandra Viegas Cortez da. Portal de serviços públicos e de informação ao cidadão: estudo de casos no Brasil. 2000. 172f. Tese (Doutorado em Administração) - Programa de Pós-Graduação em Administração - Faculdade de Economia, Administração e Contabilidade da Universidade de São Paulo, São Paulo, 2000.

; SANTOS, Ghabryelle Schwarzbach dos. O uso de meios eletrônicos no relacionamento do parlamentar com o cidadão nos municípios brasileiros. Organização \& Sociedade, Salvador, v.12, n.35, p.6989, out./dez. 2005.

CRESWELL, J. W. Qualitative inquiry and research design: choosing among five traditions. Thousand Oaks: Sage Publications, 1997.

Projeto de pesquisa: método qualitativo, quantitativo e misto. Porto Alegre: Artmed, 2007.

DINIZ, E. H. Uso do comércio eletrônico em órgãos do governo. Relatório 18/2000 Núcleo de Pesquisas e Publicações. São Paulo: Eaesp/FGV, 2000. 100 p.

FAORO, Raymundo. Os donos do poder: formação do patronato político brasileiro. São Paulo: Globo, 1998. v.2. 
FARAH, Maria Ferreira Santos. Inovação e governo local no Brasil contemporâneo. In: JACOBI, Pedro; PINHO, José Antônio Gomes de. (Org.). Inovação no campo da gestão pública local: novos desafios, novos patamares. Rio de Janeiro: FGV, 2006.

JOFFRE NETO, Joaquim Marcelino. Câmaras municipais no Brasil: ascensão e declínio. São Paulo: EaespFGV, 2003.

KERBAUY, Maria Teresa Miceli. O tradicionalismo em declínio: mudanças político-institucionais e tendências eleitorais após 1964 no interior paulista. Perspectivas, São Paulo, n.16, p.213-231, 1993.

. As câmaras municipais brasileiras: perfil de carreira e percepção sobre o processo decisório local. Opinião Pública, Campinas, SP, v.11, n.2, p.337-365, out. 2005.

KUSCHNIR, Karina. Política e mediação cultural: um estudo da Câmara Municipal do Rio de Janeiro. Rio de Janeiro. Dissertação (Mestrado em Antropologia Social) - Universidade Federal do Rio de Janeiro, 1993.

Política e sociabilidade: um estudo de antropologia social. Rio de Janeiro. Tese (Doutorado em Antropologia Social) - Universidade Federal do Rio de Janeiro, 1998.

LEVY, P. Ciberdemocracia. Lisboa: Instituto Piaget, 1999.

LOPEZ, Feliz G. A política cotidiana dos vereadores e as relações entre Executivo e Legislativo em âmbito municipal: o caso do município de Araruama. Revista de Sociologia e Política, n.22, p.153-177, jun.2004.

LOUREIRO, Maria Rita; ABRUCIO, Fernando Luiz. Política e reformas fiscais no Brasil recente. Revista de Economia Política, São Paulo, ano 24, n.1, p.50-72, jan./mar. 2004.

MARTINS, Humberto Falcão. A ética do patrimonialismo e a modernização da administração pública brasileira. In: MOTTA, Fernando C. Prestes e CALDAS, Miguel P. (Org.). Cultura organizacional e cultura brasileira. São Paulo: Atlas, 1997.

MEIRELLES, Hely Lopes. Direito municipal brasileiro. São Paulo: Malheiros, 1988.

MENEZES, Graziela Arakawa Freire de. Análise do grau de maturidade de iniciativas de governo eletrônico em governos estaduais: um estudo de caso no governo da Bahia. In: ENCONTRO DE ADMINISTRAÇÃO PÚBLICA E GOVERNANÇA, II, 2006, São Paulo. Anais... Rio de Janeiro: Anpad, 2006.

MIGUEL, Luís Felipe. Representação política em 3-D: elementos para uma teoria ampliada da representação política. Revista Brasileira de Ciências Sociais, São Paulo, v.18, n.51, p.123-193, fev. 2003.

Impasses da accountability: dilemas e alternativas da representação política. Revista de Sociologia Política, Curitiba, n.25, p.25-38, nov. 2005.

MORAES, Filomeno. Executivo e Legislativo no Brasil pós-Constituinte. São Paulo em Perspectiva, São Paulo, v.15, n.4, p.45-52, 2001.

MORAES, Patrícia B. Cidade, comunicação e tecnologia da informação: uma análise de portais governamentais brasileiros. 2004. Dissertação (Mestrado em Comunicação) - Faculdade de Comunicação, Universidade Federal da Bahia, Salvador, 2004.

O’DONNELL, Guillermo. Democracia delegativa? Novos Estudos, São Paulo, n.31, p.25-40, out. 1991. 
Accountability horizontal e novas poliarquias. Lua Nova, São Paulo, n.44, p.27-54, 1998.

PINHO, José Antonio Gomes de. Accountability em portais estaduais e municipais no Brasil: realidades distantes das promessas. In: ENCONTRO DE ADMINISTRAÇÃO PÚBLICA E GOVERNANÇA, II, 2006, São Paulo. Anais... Rio de Janeiro: Anpad, 2006.

Investigando portais de governo eletrônico de estados no Brasil: muita tecnologia, pouca democracia. Revista de Administração Pública, Rio de Janeiro, ano 42, n.3, p.471-493, maio/jun. 2008.

; SACRAMENTO, Ana Rita Silva. Transparência na administração pública: o que mudou depois da Lei de Responsabilidade Fiscal? Um estudo exploratório em seis municípios da Região Metropolitana de Salvador. In: ENCONTRO DE ADMINISTRAÇÃO PÚBLICA E GOVERNANÇA, I, 2004, Rio de Janeiro. Anais... Rio de Janeiro: Anpad, 2004.

Accountability: já podemos traduzi-la para o português? Revista de Administração Pública, Rio de Janeiro, ano 43, n.6, p.1343-1368, nov./dez. 2009.

PÓ, Marcos Vinicius; ABRUCIO, Fernando Luiz. Desenho e funcionamento dos mecanismos de controle e accountability das agências reguladoras brasileiras: semelhanças e diferenças. Revista de Administração Pública, Rio de Janeiro, v.40, n.4, p.679-98, jul./ago. 2006.

PRADO, O. Governo eletrônico e transparência: a publicização das contas públicas das capitais brasileiras. 2004. 180p. Dissertação (Mestrado em Administração Pública e Governo) - Escola de Administração de Empresas de São Paulo da Fundação Getulio Vargas, São Paulo, 2004.

PRALON, Eliana M., FERREIRA, Gabriela Nunes. Centralidade da Câmara Municipal de São Paulo no processo decisório. In: ANDRADE, Regis de Castro (Org.). Processo de governo no município e no estado de São Paulo. São Paulo: Editoria da Universidade de São Paulo, 1998.

RIBEIRO FILHO, José Francisco; CAMPELO, Sebastião Marcos; ARAÚJO, Fábio da Silva. Os websites dos tribunais de Contas como instrumentos de accountability: uma análise empírica das informações disponibilizadas. In: ENCONTRO DA ANPAD, XXIX, 2005, Brasília, DF. Anais... Rio de Janeiro: Anpad, 2005 .

RUEDIGER, Marco Aurélio. Governo eletrônico e democracia: uma análise preliminar dos impactos e potencialidades na gestão pública. Organização \& Sociedade, Salvador, v.9 n.25, p.29-43, set./dez. 2002.

SANTANA. Jair Eduardo. Roteiro prático do vereador. Belo Horizonte: Del Rey, 1995.

SANTOS, F. Novas e velhas verdades sobre organização legislativa e as democracias. Dados Revista de Ciências Sociais, Rio de Janeiro, v.41, n.1, 1998.

SANTOS, José Carlos Sales dos. Informação e democracia digital: possibilidades de participação nos websites dos deputados da Assembleia Legislativa do Estado da Bahia. In: COLÓQUIO INTERNACIONAL SOBRE PODER LOCAL, XI, 2009, Salvador. Anais... Salvador: Ciags/UFBA, 2009.

SANTOS, W. G. Razões da desordem. Rio de Janeiro: Rocco, 1993.

SCHWARTZMAN, Simon. Bases do autoritarismo brasileiro. Rio de Janeiro: Campus, 1988.

SOUZA, Antônio Ricardo de. Agências reguladoras e seus modelos de gestão: uma análise na Aneel e Anatel. 2007. 245f. Tese (Doutorado em Administração) - Núcleo de Pós-Graduação em Administração NPGA, Universidade Federal da Bahia, Salvador, 2007. 
STAKE, R. E. The art of case study research. Thousand Oaks: Sage Publications, 1995.

VAZ, José Carlos. Limites e possibilidades do uso de portais municipais para promoção da cidadania: a construção de um modelo de análise e avaliação. Tese (Doutorado em Administração) - Curso de Doutorado em Administração de Empresas da Eaesp, Fundação Getulio Vargas, São Paulo, 2003.

WEBER, Max. Economia y sociedad.México: Fondo de Cultura Económica, 1944. v.I.

WHITAKER, Francisco. O que é vereador. São Paulo: Brasiliense, 1992.

ZANI, Felipe Barbosa. Em busca de informações nas câmaras municipais: uma análise do controle social exercido por grupos de acompanhamento do Legislativo. In: COLÓQUIO INTERNACIONAL SOBRE PODER LOCAL, XI, 2009, Salvador. Anais... Salvador: Ciags/UFBA, 2009. 